\title{
The added value and competitive advantage of Islamic banks in Indonesia
}

\author{
Sugeng Suroso ${ }^{a^{*}}$
}

${ }^{a}$ Universitas Bhayangkara Jakarta Raya, Indonesia

\begin{tabular}{l}
\hline C H R O N I C L E \\
\hline Article history: \\
Received August 26, 2021 \\
Received in revised format \\
September 292021 \\
Accepted November 242021 \\
Available online \\
November 24 2021 \\
\hline Keywords: \\
Competitive advantage \\
Islamic Bank \\
Added value
\end{tabular}

1. Introduction

The current era of information and science has changed the banking business to become more and more competitive. The development of the banking business is no longer centered on industrial machines but also on the ability of human resources to innovate. Intangible resources will be more critical when compared to tangible resources. It will be an exciting research topic in accounting and finance (Bozzolan et al., 2006), which then becomes a question of how relevant and reliable the financial statements are used as a tool for reporting on company assets (Lev, 2017). Some previous studies found differences in market value and company book value (Rehman et al., 2013); this allegation is a hidden value in the company's financial statements. This hidden value is called intellectual capital. In its development, Intellectual capital is divided into three components, namely human, organizational and external (Bontis, 1998). The main framework of intellectual capital is the theory presented by Barney in 1991, namely the resource-based theory or known as the RBT theory. In this theory, it is stated that strategic assets that can create competitive advantage are VRIN assets, namely is valuable, very rare, difficult to imitate and irreplaceable assets (Barney \& Arikan, 2006). Intellectual capital is the primary resource and is the driver of value creation (Andreeva \& Garanina, 2016). Intellectual capital has a crucial role in value-added and in maintaining competitive advantage. In resource-based theory, intellectual capital will significantly affect competitive advantage by producing unique resource values. More efficient management of intellectual capital will be able to make competitive advantages in a faster time (Tyskbo, 2019). The importance of intellectual capital to create competitive advantage and corporate awareness in managing intellectual capital in Indonesia is the reason for the importance of this research. The contribution of intellectual capital in generating competitive advantage in companies, especially in Islamic banking in Indonesia, has not been studied in more depth, mainly how Islamic banking can manage intellectual capital well and maintain its competitive advantage. Most intellectual capital research in Indonesia has linked intellectual capital to

* Corresponding author.

E-mail address: sugeng.suroso@ubharajaya.ac.id (S. Suroso)

C 2022 Growing Science Ltd. All rights reserved.

doi: 10.5267/j.ac.2021.11.004 
performance (Suroso et al., 2017) and financial statement disclosure practices (Basyith, 2016). Based on an argument, the problem in a study is: "Is there a difference in the efficiency of intellectual capital management between Islamic banking, which has a sustainable competitive advantage, and Islamic banking, which has an unsustainable competitive advantage". In addition, to understand differences in intellectual capital management efficiency, this study also aims to test the consistency of RBT theory, which emphasizes whether VRIN's resources can contribute to competitive advantage.

Based on the study about performance bank conventional with a bank with principal sharia indicates things as follows (Suroso et al., 2017):

a. During the period December 2014 until May 2016, 10 big bank conventional show drop capitalization market as big as $42.8 \%$, compared with a bank with principal sharia which only experience drops as big as $8.5 \%$,

b. Conventional banks experienced a decrease in net profit of 42 billion US dollars in 2008, while in the same period, Islamic banks earned 4.6 billion dollars.

c. Conventional banks' total asset reserves increased $36 \%$ to US $\$ 17.4$ trillion. However, other banks with principal sharia grew $55 \%$ to reach 147-billion-dollar US on quarter first 2008 from 94-billion-dollar US on quarter first 2006. Thus, total equity for conventional banks and banks with principal sharia is $24 \%$ and $36 \%$ during this enhancement period.

d. Ratio leverage (assets/equity) bank conventional is 16.6 times in the year 2006 which increases to 18.2 times in the year 2008. Ratio leverage bank traditional almost three-time from a bank with principal sharia as big as 5.8 times in the year 2006 Becomes and 6.6 times in the year 2008.

e. Five from ten big banks conventional get help finance by total 163 -billion-dollar US or $26 \%$ help bank combined capital from the government. In comparison, only one institution finance Islam, need endorsement government for arranging and trade the stock which postponed. At the end of 2009, the bank with principal sharia no need government or party anywhere to support rescue finance.

\section{Literature review and hypothesis}

\subsection{Resource-based theory (RBT)}

Resource-based theory (RBT) is developed more from theory rent economy by Ricardo and theory Structure, Behavior, and performance by Porter (Rehman et al., 2013). The theory this appears from the fact that seems question strategic: why something company could outperform company other and maintain performance which tall. The company that makes and controls source power alone has superiority in maintaining the advantage on a company that buys or gets source power from outside organizations. The source power and unique control company are essential for reaching and preserving performance which is consistent and superior (Widyaningdyah \& Aryani, 2013). Source power unique, called RBT, is source power that is valuable, rare, easy reproduced, and no, there is the comparison. Score it means could be used for an activity company, it means seldom owned by any company. No existence imitation could interpret that source power protected from possibility imitated by a competitor. No replaced means source power only owned by company-specific and no could be replaced by product other (Barney et al. 2001). Type source power could motivate the company to forget competitive superiority.

\subsection{Intellectual capital}

World business confesses that capital intellectuality is the source main creation score, performance business, and competitive superiority. Studies about capital intellectualism have been done since the 1990s (Barney \& Arikan, 2006). Capital man is focused centrally from studying capital intellectual During that period. Bontis (1999) looks at assets, not form, as goodwill, as an asset scored for an organization. Study on asset form, knowledge, and source power man then followed by study about capital intellect. Barney and Jae (2010) introduce draft asset no form as an asset not seen. Strategy company which success depends on using emotional support no form organization as well as asset form. (Chen et al., 2005). In time then, capital man only consists of worker manuals, different from the worker in the modern moment. Now, that organization considers the worker manual as cost, but this organization must consider the worker as an asset (Jardon \& Martos, 2012). Organizations need to control and reduce cost, but human capital in the organization also needs to grow. A professional worker not only has experience but must also know. Because knowledge is an asset big something organization (Yaseen et al., 2016). Component capital intellectual has developed since 1991. Model this consists of four-element principal capital intellectual on man, customer, process, and update/development (Jardon \& Martos, 2012). The capital customer is then categorized as part of capital relational. The development of these components is then considered as a capital innovation, which is combined with the capital process to become a capital structure. Man, relational, and capital structure are part mainly from the intellectual capital. Models other generally use component this, temporarily there are many from which they varied (Suroso et al., 2017).

\subsection{Competitive advantage}

An organization can enjoy high profits by generating higher economic value than other organizations in its industry (Rezaee \& Jafari, 2015). In addition, it is also said that the most important thing is to maintain the suitability and support capacity of the upper party, which is more often referred to as the supported party (Barney \& Jae, 2010). The advantages in RBT are unusual gains or better-than-expected returns using the organization's unique capacities (Dumay et al., 2019). 
Competitive advantage is divided into a competitive advantage on a logistics basis (Pucar, 2012) and a competitive advantage on an asset basis (Barney et al., 2001). In this review, an asset-based advantage approach is used as described in the RBT. More carry-on Barney 2006 (Barney \& Arikan, 2006)) say that company has sustained competitive advantage if source power which used fulfil condition as following:

- Have Value (Valuable)

Source power or capability company said worth if a company could create a score for customer with utilize the opportunity and neutralize the threat from the environment external.

- Scarcity supply (Rare)

Source power will be more valuable when there is a shortage of supply. If some company has source power which is Specific, a little competitor, and source power is required for fulfilling customer needs, so source power the cloud Becomes source superiority competitive.

- Expensive for imitated (Costly to imitation)

If competitor must emit much money for Imitate function which same, or if competitor no could Imitate function business, so source power or ability company said too expensive for imitated.

- No availability substitution (Non substitutable)

No, there is a replacement for source power or ability from the company. Competitors could do an activity which is the same, without resources.

\subsection{Hypothesis}

$\mathbf{H}_{1}$ : There is a difference in the value of human capital, between the sustainable competitive advantage group of companies and the unsustainable competitive adventive group of companies.

$\mathbf{H}_{2}$ : There is a difference in the value of structural capital, between the sustainable competitive advantage group of companies and the unsustainable competitive adventive group of companies.

$\mathbf{H}_{3}$ : There is a difference in the value of capital employed, between the sustainable competitive advantage group of companies and the unsustainable competitive adventive group of companies.

\section{Research}

The analysis tool uses comparative analysis with Independent samples t-test because the test data has a ratio scale for two independent samples. Statistical testing in this study, assisted by SPSS 26.0 software. The test sequences are as follows:

a. The sample is divided into two groups. That is, Companies with sustainable competitive advantages (SCA) and unsustainable competitive advantages (UCA). The criteria used are to calculate the ROCE of each company and have a sustainable competitive advantage so that only companies with an average ROCE higher than the industry average for two years can be observed. These criteria represent the work of Spanos and Rioukas (2001)

b. test $t$ for sample independent

Before operating the test to sample free, need test homogeneity/test F / test Levene. Test this done to ensure that every group data has variance which is the same. If the variances are the same, the t-test uses the Equal Variance Assumed score, and if the variances are not the same, then the Equal Variance not Assumed is used. Criteria testing which used with level significance $=5 \%$.

\subsection{Definition of operational and measurement variables}

\subsubsection{Intellectual capital}

Variable IC is score efficiency management Intellectual capital as has been declared by Public (Public, 2004). Measurement Intellectual capital use value-added intellectual capital (VAIC) with steps is as follows:

a. Count score plus which formulated as follows:

$V A=O P+E C+D+A$

where $O P, E C, D$ and $A$ are operating profit, employee costs, depreciation and amortization, respectively.

b. The next step is to count the score of human capital(HC), Capital structural (SC), and capital employed (CE). 
The next step is to calculate the value of $H C, S C$ and $C E$.

$H C=$ Total wages and salaries used by the company

$S C=$ is a subtraction of VA with $\mathrm{HC}$

$C E=$ capital employed is the capital used

c. Count ratio efficiency for each capital. On basic VAIC is an amount from three indicators separated (Pulić, 2008), that is:

$V A I C=H C E+S C E+C E E$

where VAIC, CEE, HCE and SCE are Value added intellectual coefficient, Capital employed efficiency, VA/CE, Human capital efficiency, VA/HC and Structural capital efficiency, SC/VA, respectively.

\subsubsection{Sustainable competitive advantage}

Sources of competitive advantage are classified into four, namely customer relationships, supplier relationships, intellectual property, and fixed asset management (Tang \& Liou, 2010). More carry on by mathematics could prove that combination from proxy connection with customer, rich intellectual, and management asset permanent the will shape a new ratio named ROCE (Return on Capital Employed). Formulation ROCE could calculate as follows (Kwong et al., 1995):

$$
R O C E=\frac{(\mathrm{R}-0 p \operatorname{Exp})}{(T A-T L)}
$$

where ROCE, $O p \operatorname{Exp}, R, T A$ and $T L$ are Return on Capital Employed, Oration Expense, Revenue, Total Assets and Total Liabilities, respectively.

\section{Results}

\subsection{Sample data divided into two groups SCA and UCA}

From the processed data, the average ROCE in the industry is 0.0289 . Sample data from the SCA and UCA groups is as follows:

Tabel 1

SCA Group and UCA Group

\begin{tabular}{ccccc}
\hline BANK & ROCE & GROUPS & BANK & ROCE \\
\hline BTP & 0.424869 & SCA & MUA & 0.020312 \\
BNI & 0.237809 & SCA & VIC & -0.07119 \\
BSI & 0.097427 & SCA & ALD & -0.05843 \\
MGA & 0.079963 & SCA & BJB & -0.20545 \\
BRI & 0.074289 & SCA & & -0.38098 \\
BCA & 0.065025 & SCA & & UCA \\
BUK & 0.039655 & SCA & & \\
\hline
\end{tabular}

The Companies that are included in the sustainable competitive adventive (SCA) group are companies that have a return on employed capital (ROCE) above the industry average (Kwong et al., 1995). Test hypothesis uses analysis comparison with independent samples t-test because data tested have scale ratio for two samples free.

Condition testing with independent samples t-test is :

- Scale data intervals/ratio.

- Group data each other free or not in pairs.

- Data per group is distributed normally.

- Data per group no there are outliers.

- the variance between group identical or homogeneous

From results processed data, the obtained grouping SCA and UCA is as follows :

Table 2

Group Sustainable Competitive Advantage

\begin{tabular}{lccccc}
\hline NO & BANK & CEE & HCE & SCE & 0.497 \\
2 & BTP & 0.673 & 2.121 & 0.371 & 3.291 \\
3 & BNI & 0.375 & 1.601 & 0.252 & 0.346 \\
4 & BSI & 0.372 & 1.362 & 1.987 & 0.280 \\
5 & MGA & 0.224 & 1.445 & 0.219 & 0.412 \\
6 & BRI & 0.237 & 1.286 & 1.948 & 0.171 \\
7 & BCA & 0.109 & 1.713 & 1.261 & 1.566 \\
\hline
\end{tabular}


Table 2

Group Sustainable Competitive Advantage

\begin{tabular}{|c|c|c|c|c|c|}
\hline $\mathrm{NO}$ & BANK & CEE & HCE & SCE & VAIC \\
\hline 1 & BTP & 0.673 & 2.121 & 0.497 & 3.291 \\
\hline 2 & BNI & 0.375 & 1.601 & 0.371 & 2.346 \\
\hline 3 & BSI & 0.372 & 1.362 & 0.252 & 1.987 \\
\hline 4 & MGA & 0.224 & 1.445 & 0.280 & 1.948 \\
\hline 5 & BRI & 0.237 & 1.286 & 0.219 & 1.742 \\
\hline 6 & $\mathrm{BCA}$ & 0.109 & 1.713 & 0.412 & 2.234 \\
\hline 7 & BUK & 0.133 & 1.261 & 0.171 & 1.566 \\
\hline
\end{tabular}

Source: data processed

Results processing data based on criteria outlined previously obtained seven company enter in measures SCA and five company enter criteria UCA. Each group will analyze factors determinant VAIC will have a difference which is significant.

\subsection{Statitsical observations}

Table 4

The information of some descriptive staitsics for SCA and UCA groups

\begin{tabular}{|c|c|c|c|c|c|}
\hline & & CEE & $\mathrm{HCE}$ & SCE & VAIC \\
\hline \multirow[t]{2}{*}{$\mathrm{N}$} & Valid & 7 & 7 & 7 & 7 \\
\hline & Missing & 0 & 0 & 0 & 0 \\
\hline \multicolumn{2}{|c|}{ mean } & .3033 & 1.5413 & .3146 & 2.1591 \\
\hline \multicolumn{2}{|c|}{ median } & .2370 & 1.4450 & .2800 & 1.9870 \\
\hline \multicolumn{2}{|c|}{ Std. Deviation } & .19321 & .30394 & .11606 & .56593 \\
\hline \multicolumn{2}{|c|}{ Minimum } & .11 & 1.26 & .17 & 1.57 \\
\hline \multicolumn{2}{|c|}{ Maximum } & .67 & 2.12 & .50 & 3.29 \\
\hline & CEE & $\mathrm{HCE}$ & SCE & VIC \\
\hline \multirow[t]{2}{*}{$\mathrm{N}$} & Valid & 7 & 7 & 7 & 7 \\
\hline & Missing & 0 & 0 & 0 & 0 \\
\hline \multicolumn{2}{|c|}{ mean } & -.0197 & .2553 & .6470 & .8826 \\
\hline \multicolumn{2}{|c|}{ median } & .0450 & .5490 & .4170 & 1.3990 \\
\hline \multicolumn{2}{|c|}{ Std. Deviation } & .24650 & 1.45859 & .57856 & 1.47638 \\
\hline \multicolumn{2}{|c|}{ Minimum } & -.52 & -2.68 & .08 & -1.80 \\
\hline \multicolumn{2}{|c|}{ Maximum } & .23 & 1.71 & 1.76 & 2.35 \\
\hline
\end{tabular}

Table 4 shows that the average score VAIC on company group SCA is taller $(2,1591)$ than company group UCA (0.8876). Results show that the creation score (value creation) on company SCA is taller than company UCA. Results are also supported with components shaper VAIC, HCE, SCE, and CEE, each on company SCA has a scoring average taller than company UCA.

\subsection{Test T for sample independent}

Condition for test $\mathrm{t}$ sample free is data must be normal, as well as must be homogeneous. To that need tested more formally test normality and homogeneity.

\section{Normality tset}

Test Normality Data Test one Sample Kolmogorov Smirnov test is the test done for knowing tool test analysis used for doing tests differently (parametric or non-parametric). Test normality This aims to test something model regression is in model regression, variable dependent and independent have distribution normal, test normality the shown on the table following.

Table 5

The results of One-Sample Kolmogorov-Smirnov

\begin{tabular}{|c|c|c|c|c|c|}
\hline & & $\mathrm{CEE}$ & $\mathrm{HCE}$ & SCE & VAIC \\
\hline $\mathrm{N}$ & & 12 & 12 & 12 & 12 \\
\hline \multirow[t]{2}{*}{ Normal Parameters, b } & mean & .1453 & .8002 & .5123 & 1.4577 \\
\hline & Std. Deviation & .29425 & 1.28617 & .46352 & 1.35328 \\
\hline \multirow[t]{3}{*}{ Most Extreme Differences } & Absolute & .134 & .255 & .263 & .233 \\
\hline & Positive & .134 & .156 & .263 & 171 \\
\hline & negative & -.118 & -.255 & -.175 & -.233 \\
\hline Test Statistics & & .134 & .255 & .263 & .233 \\
\hline asymp. Sig. (2-tailed) & & $.200 \mathrm{c}, \mathrm{d}$ & $.030 \mathrm{c}$ & $.021 \mathrm{c}$ & $.072 \mathrm{c}$ \\
\hline
\end{tabular}

Source: Data processed 
Score statistics Kolmogorov-Smirnov (Dmax) CEE $=0.134, \mathrm{HCE}=0.255$ SCE 0.263 VAIC 0.233, Score critical Kolmogorov-Smirnov with $n=12$ and level significance $=0.05$ is 0.375 . So could concluded that data the distribute normal.

\subsection{Test of Homogeneity/ test F / test Levene}

Test this done to ensure that every group data has variance which is the same. If the variance is the same, the t-test uses the Equal Variance Assumed and the Equal Variance not Assumed if the variant is not the same. Criteria testing which used with level significance $=5 \%$.

\section{Table 6}

The results of Homogeneity

\begin{tabular}{|c|c|c|c|c|c|}
\hline & & Levene Statistics & df1 & df2 & Sig. \\
\hline \multirow[t]{4}{*}{$\mathrm{CEE}$} & Based on mean & .257 & 1 & 10 & .623 \\
\hline & Based on median & .201 & 1 & 10 & .663 \\
\hline & Based on median and with adjusted df & .201 & 1 & 9.101 & .664 \\
\hline & Based on trimmed mean & .248 & 1 & 10 & .629 \\
\hline
\end{tabular}

Since the score sig is as big as 0.623 , more significant than 0.05 , data is homogeneous and fulfils the condition for test independent sample t-test.

Table 7

The results of Homogeneity

\begin{tabular}{|c|c|c|c|c|c|}
\hline & & Levene Statistics & df1 & df2 & Sig. \\
\hline \multirow[t]{4}{*}{$\mathrm{HCE}$} & Based on mean & 4.268 & 1 & 10 & .066 \\
\hline & Based on median & 2,608 & 1 & 10 & .137 \\
\hline & Based on median and with adjusted df & 2,608 & 1 & 4.491 & .174 \\
\hline & Based on trimmed mean & 3,519 & 1 & 10 & .090 \\
\hline
\end{tabular}

Source : Data processed

Since the score sig as big as 0.066 is more significant than 0.05 , data is homogeneous and fulfils the condition for independent sample t-test.

Table 8

The results of Homogeneity

\begin{tabular}{|c|c|c|c|c|c|}
\hline & & Levene Statistics & df1 & df2 & Sig. \\
\hline \multirow[t]{4}{*}{ SCE } & Based on mean & 7.086 & 1 & 10 & .064 \\
\hline & Based on median & 5.487 & 1 & 10 & .071 \\
\hline & Based on median and with adjusted df & 5.487 & 1 & 4.385 & .073 \\
\hline & Based on trimmed mean & 6,808 & 1 & 10 & .066 \\
\hline
\end{tabular}

Source : Data processed

Since the score sig as big as 0.064 is more significant than 0.05 , the data is homogeneous and fulfils the condition for independent sample t-test.

Table 9

The results of Homogeneity

\begin{tabular}{|c|c|c|c|c|c|}
\hline & & Levene Statistics & df1 & df2 & Sig. \\
\hline \multirow[t]{4}{*}{ VAIC } & Based on mean & 4092 & 1 & 10 & .071 \\
\hline & Based on median & 3,647 & 1 & 10 & .085 \\
\hline & Based on median and with adjusted df & 3,647 & 1 & 6,577 & .100 \\
\hline & Based on trimmed mean & 4.007 & 1 & 10 & .073 \\
\hline
\end{tabular}

Source : Data processed

Because the score sig as big as 0.071 more significant than 0.05 , so data is homogeneous and fulfil the condition for independent sample t-test.

\subsection{The results of independent t-test}

Independent sample t-test is tested comparatively or tests differently for knowing if there is a difference mean or average which means Among two groups free which scale interval or ratio. Two groups are free, which means two groups are not in pairs. It means source data originated from two subjects that are different. Before done test t-test (independent t-test) done test similarity variant (homogeneity) with F test (Levene's tests). 
Base taking decision

1. If score Sig. ((2-tailed) $<0.05$, so there is a difference which significant among group SCA with group UCA

2. If score Sig. ((2-tailed) $>0.05$, so no, there is a difference which significant among group SCA with group UCA

Table 10

Test different independent sample test CEE

\begin{tabular}{|c|c|c|c|c|c|c|c|c|c|c|}
\hline \multicolumn{11}{|c|}{ Independent Samples Test } \\
\hline & & \multicolumn{5}{|c|}{ Levene's Test } & \multicolumn{3}{|c|}{ t-test for Equality of Means } & \\
\hline & & \multirow[b]{2}{*}{$\mathrm{F}$} & \multirow[b]{2}{*}{ Sig. } & \multirow[b]{2}{*}{$\mathrm{t}$} & \multirow[b]{2}{*}{ df } & \multirow{2}{*}{$\begin{array}{l}\text { Sig. (2- } \\
\text { tailed) }\end{array}$} & \multirow{2}{*}{$\begin{array}{c}\text { mean } \\
\text { difference }\end{array}$} & \multirow{2}{*}{$\begin{array}{l}\text { Std. Error } \\
\text { Difference }\end{array}$} & \multicolumn{2}{|c|}{$\begin{array}{l}\text { 95\% Confidence interval of the } \\
\text { difference }\end{array}$} \\
\hline & & & & & & & & & Lower & Upper \\
\hline \multirow[t]{2}{*}{ CEE } & Equal variances & .258 & .622 & 2.807 & 10 & .019 & .37951 & .13518 & .07830 & .68072 \\
\hline & Equal variances & & & 2,632 & 6,704 & .035 & .37951 & .14417 & .03551 & .72351 \\
\hline
\end{tabular}

Source : Data processed

Since the score sig. (2-tailed) as big as 0.0.019 more small from 0.05, so there is a difference which significant Among group SCA and group UCA. Results test t show that there is a difference which significant, Capital Employed Efficiency (CEE) with group SCA and UCA. Results show that companies with superior competitive sustainable (SCA), which have efficiency on capital, can create score plus or manage asset intellect, taller than companies with unsustainable competitive adventive (UCA). To that so hypothesis 1 where there is difference Capital Employed Efficiency (CEE) which real Among group SCA and UCA fulfilled. Table 12 and Table 13 present the results for SCE and VAIC.

Table 11

Test different independent sample test HCE

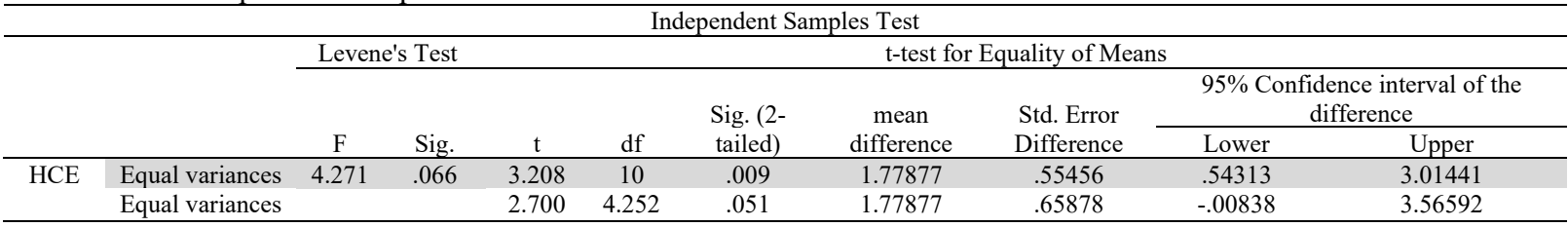

Source : Data processed

Table 12

Test different independent sample test SCE

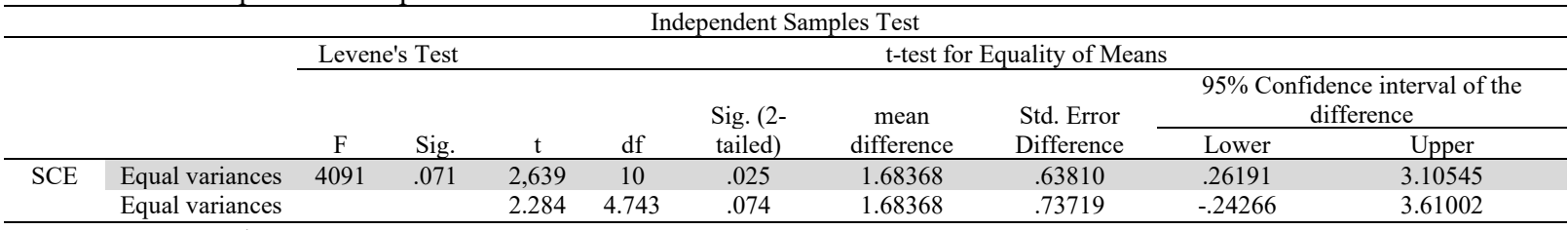

Source : Data processed

Table 13

Test different independent sample test VAIC

\begin{tabular}{|c|c|c|c|c|c|c|c|c|c|c|}
\hline \multicolumn{11}{|c|}{ Independent Samples Test } \\
\hline & & \multicolumn{5}{|c|}{ Levene's Test } & \multicolumn{3}{|c|}{ t-test for Equality of Means } & \\
\hline & & \multirow[b]{2}{*}{$\mathrm{F}$} & \multirow[b]{2}{*}{ Sig. } & \multirow[b]{2}{*}{$\mathrm{t}$} & \multirow[b]{2}{*}{$\mathrm{df}$} & \multirow{2}{*}{$\begin{array}{l}\text { Sig. (2- } \\
\text { tailed) }\end{array}$} & \multirow{2}{*}{$\begin{array}{c}\text { mean } \\
\text { difference }\end{array}$} & \multirow{2}{*}{$\begin{array}{l}\text { Std. Error } \\
\text { Difference }\end{array}$} & \multicolumn{2}{|c|}{$\begin{array}{l}95 \% \text { Confidence interval of the } \\
\text { difference }\end{array}$} \\
\hline & & & & & & & & & Lower & Upper \\
\hline \multirow[t]{2}{*}{ VAIC } & Equal variances & 4091 & .071 & 2,639 & 10 & .025 & 1.68368 & .63810 & .26191 & 3.10545 \\
\hline & Equal variances & & & 2.284 & 4.743 & .074 & 1.68368 & .73719 & -.24266 & 3.61002 \\
\hline
\end{tabular}

Source : Data processed

\section{Discussion}

5.1 There is a difference in the value of human capital (HCE), between the sustainable competitive advantage group of companies and the unsustainable competitive adventive group of companies.

The average HCE for the SCA group was 1.541, while for the UCA group, it was (negative) 0.238. There was a significant difference between the SCA group and the SCA group because of the value of sig. (2-tailed) 0.019 is smaller than 0.05 . These results indicate a significant difference, Human Capital Efficiency (HCE), with the SCA and UCA groups. This means that companies with a sustainable competitive advantage (SCA) have more efficient human capital and can create added value in managing their intellectual assets than companies in the UCA group. For this reason, hypothesis 1 is fulfilled 
5.2 There is a difference in the value of structural capital, between the sustainable competitive advantage group of companies and the unsustainable competitive adventive group of companies.

The average value of structural capital efficiency (SCE) for the SCA group is 0.315 , while the average value for the UCA group is 0.067 . There is a significant difference between SCE in the SCA group and the UCA group. Because of the value of sig. (2-tailed) 0.019 is smaller than 0.05 , so These results indicate that companies with a sustainable competitive advantage (SCA) have efficiency and can create added value in managing their intellectual assets. For this reason, hypothesis 2 is fulfilled

5.3 There is a difference in the value of capital employed, between the sustainable competitive advantage group of companies and the unsustainable competitive adventive group of companies.

From the data, the average CEE value for the SCA group is 0.33, while for the UCA group, it is (negative) 0.076 . The results of the t-test show the value of sig. (2-tailed) 0.019 is smaller than 0.05 , so there is a significant difference in the SCA and UCA groups in Capital Employed Efficiency (CEE). This shows that companies that can manage capital employed more efficiently will be able to create better added value, when compared to the UCA group of companies. For this reason, hypothesis one, where there is a significant difference in Capital Employed Efficiency (CEE) between the SCA and UCA groups, is fulfilled.

The average HCE for the SCA group was 1.541, while for the UCA group, it was (negative) 0.238 . There was a significant difference between the SCA group and the SCA group because of the value of sig. (2-tailed) 0.019 is smaller than 0.05. These results indicate a significant difference, Human Capital Efficiency (HCE), with the SCA and UCA groups. This means that companies with a sustainable competitive advantage (SCA) have more efficient human capital and can create added value in managing their intellectual assets than companies in the UCA group. For this reason, hypothesis 2 is fulfilled.

In the hypothesis, there is a difference between CEE, HCE, and SCE between SCA and UCA companies; for that, then the hypothesis is proven. VAIC for companies included in the SCA shows a higher average result of 2.1591 than companies included in the UCA, 0.8826. These results can also support Tang and Liou's (2010) and Lin and Huang's (2011) research. Tang and Liou's (2010) explorations show differences in the parts that make up VAIC. Namely, companies with a sustainable competitive advantage (SCA) and companies with an unsustainable advantage (UCA), especially in knowledge management. Companies that have a sustainable competitive advantage will carry out better employee knowledge management activities,

The results of this study also support the theory of Lin and Huang (2011), which states that there are differences between companies that focus on tangible assets and companies that focus on intangible assets. have better resource performance. Organizations with high immaterial resource strength have a better future and can maintain their competitive advantage consistently. Similarly, Kamukama et al.'s (2010) research shows that competitive advantage becomes a mediating tool between the company's added value and company performance.

In Lin and Huang's (2011) test, the terms used are competitive advantage and super performance, which conceptually can be interpreted as replacing each other in the VAIC assessment.

From the discussion above, it can be concluded that a company that can properly manage its capital and resources, including scientific resources, is a company that can maintain a competitive advantage. Intellectual Capital, an extraordinary resource, namely VRIN, can win in the competition as stated in RBT theory (Barney 2001, Barney \& Clark 2007).

The analysis results showed a real difference in HCE, SCE, and CEE in the two groups. The mean HCE, SCE, and CEE in the SCA group would generally give higher results. This shows that competing companies will provide additional benefits through intellectual capital and higher physical and financial assets than companies with an unsustainable competitive advantage.

The description above is associated with the hypothesis that there is a difference between CEE, HCE, and SCE between the SCA group of companies and the UCA group of companies, then the hypothesis can be accepted. The VAIC value in the SCA group showed a higher mean value of 2.1591 compared to the UCA group of 0.8826 . These results support research by Tang and Liou (2010) and Lin and Huang (2011). The research of Tang and Liou (2010) showed a significant difference in the VAIC component of the SCA group and the UCA group, mainly in knowledge management. Companies with a sustainable competitive advantage will generally monitor employee information reflected in their innovation strength. In fact,

The consequences of the results of this study can be used in the research of Lin and Huang (2011), namely the difference between companies that have more intangible assets and companies that have more tangible support. Groups of companies with more intangible assets will have better performance than companies with more tangible assets. Companies with more intangible resources will have better future possibilities and follow its prevalence by going further. The research results from Kamukama et al. (2010) show that competitive advantage is a mediating tool between intellectual capital and a company's performance. 
This research supports the exploration led by Chang (2010) that an organization will provide different sections within the VAIC section. Information technology companies will generally focus on product development and have higher HCE scores; however, if they are not supported by adequate foundations and data frameworks (SCE and CEE), it will reduce organizational productivity. From the analysis by Chang (2010), it can be explained that a company organization that has a sustainable competitive advantage will be able to improve asset management better when compared to a company organization whose competitive advantage is not sustainable, as evidenced by HCE, SCE, and CEE, which has a higher value when compared to organizations whose competitive advantage is not sustainable. The use of intellectual capital in the SCA group is also more effective when compared to the UCA group. Effectiveness in managing financial resources is the main factor in providing additional benefits to make a productive and definite contribution to the company.

\section{Conclusion}

From the results of the tests carried out, it can be concluded that the SCA group of companies has a higher VAIC value than the UCA group of companies. The SCA group of companies can also manage intellectual assets more efficiently than the UCA group of companies. The results obtained from the test are that companies that can maintain competitive advantage are companies that can provide added value to stakeholders. These results support the RBT hypothesis, as evidenced by the finding that VRIN assets can be used to provide added value for stakeholders. The results obtained from the test are that companies that can maintain competitive advantage are companies that can provide added value to stakeholders. These results support the RBT hypothesis, as evidenced by the finding that VRIN assets can be used to provide added value for stakeholders.

\section{References}

Andreeva, T., \& Garanina, T. (2016). Journal of Intellectual Capital Capital Information. Journal of Intellectual Capital, $17(2), 397-412$.

Barney, J. B., \& Arikan, A. M. (2006). The Resource-based View : Origins and Implications. 1, 123-182.

Barney, \& Jae. (2010). Gaining and Sustaining Competitive advantage. Prentice Hall.

Basyith, A. (2016). Corporate Governance, Intellectual Capital and Firm Performance. Research in Applied Economics, $8(1), 17$. https://doi.org/10.5296/rae.v8i1.8675

Bontis, N. (1998). Mapping the human capital management research trends using bibliometric analysis. Management Decision, 32(6), 63-76.

Bozzolan, S., O’Regan, P., \& Ricceri, F. (2006). Intellectual capital disclosure (ICD). Journal of Human Resource Costing \& Accounting, 10(2), 92-113. https://doi.org/10.1108/14013380610703111

Chen, M., Cheng, S., \& Hwang, Y. (2005). An empirical investigation of the relationship between intellectual capital a ... Journal of Intellectual Capital, 6(2), 159-176.

Dumay, J., La Torre, M., \& Farneti, F. (2019). Developing trust through stewardship: Implications for intellectual capital, integrated reporting, and the EU Directive 2014/95/EU. Journal of Intellectual Capital, 20(1), 11-39. https://doi.org/10.1108/JIC-06-2018-0097

Jardon, C. M., \& Martos, M. S. (2012). Intellectual capital as competitive advantage in emerging clusters in Latin America. Journal of Intellectual Capital, 13(4), 462-481. https://doi.org/10.1108/14691931211276098

Kwong, M. F. C., Munro, J. W., \& Peasnell, K. V. (1995). Commonalities Between Added Value Ratios and Traditional Return on Capital Employed. Accounting and Business Research, 26(1), 51-67. https://doi.org/10.1080/00014788.1995.9729498

Lev, B. (2017). Evaluating Sustainable Competitive Advantage. Journal of Applied Corporate Finance, 29(2), $70-75$. https://doi.org/10.1111/jacf.12234

Pucar, S. (2012). The influence of intellectual capital on export performance. Journal of Intellectual Capital, 13(2), 248261. https://doi.org/10.1108/14691931211225715

Pulic, A. (2004). Intellectual capital - does it create or destroy value? Measuring Business Excellence, 8(1), $62-68$. https://doi.org/10.1108/13683040410524757

Pulić, A. (2008). The Principles of Intellectual Capital Efficiency - A Brief Description. Croatian Intellectual Capital Center, 76, 1-24.

Rehman, W. ul, Rehman, C. A., Rehman, H. ur, \& Zahid, A. (2013). Intellectual capital performance and its impact on financial returns of companies: An empirical study from insurance sector of Pakistan. African Journal of Business Management, 5(20), 8041-8049. https://doi.org/10.5897/AJBM10.1088

Rezaee, F., \& Jafari, M. (2015). The effect of marketing knowledge management on sustainable competitive advantage: Evidence from banking industry. Accounting, 1, 69-88. https://doi.org/10.5267/j.ac.2015.12.002

Suroso, S., Widyastuti, T., Salim, M. N., \& Setyawati, I. (2017). Intellectual Capital and Corporate Governance in Financial Performance Indonesia Islamic Banking. 7(4).

Tang, Y. C., \& Liou, F. M. (2010). Does firm performance reveal its own causes? The role of bayesian inference. Strategic Management Journal, 31(1), 39-57. https://doi.org/10.1002/smj.799

Tyskbo, D. (2019). Managers' views on how intellectual capital is recognized and managed in practice: A multiple case study of four Swedish firms. Journal of Intellectual Capital, 20(2), 282-304. https://doi.org/10.1108/JIC-01-2018-0017 
Widyaningdyah, A. U., \& Aryani, Y. A. (2013). Intellectual Capital dan Keunggulan Kompetitif (Studi Empiris Perusahaan Manufaktur versi Jakarta Stock Industrial Classification-JASICA). Jurnal Akuntansi Dan Keuangan, 15(1), 1-14. https://doi.org/10.9744/jak.15.1.1-14

Yaseen, S. G., Dajani, D., \& Hasan, Y. (2016). The impact of intellectual capital on the competitive advantage: Applied study in Jordanian telecommunication companies. Computers in Human Behavior, 62, $168-175$. https://doi.org/10.1016/j.chb.2016.03.075

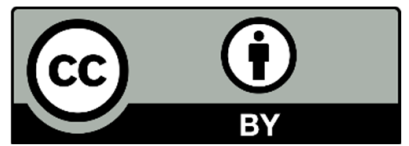

(C) 2022 by the authors; licensee Growing Science, Canada. This is an open access article distributed under the terms and conditions of the Creative Commons Attribution (CC-BY) license (http://creativecommons.org/licenses/by/4.0/). 